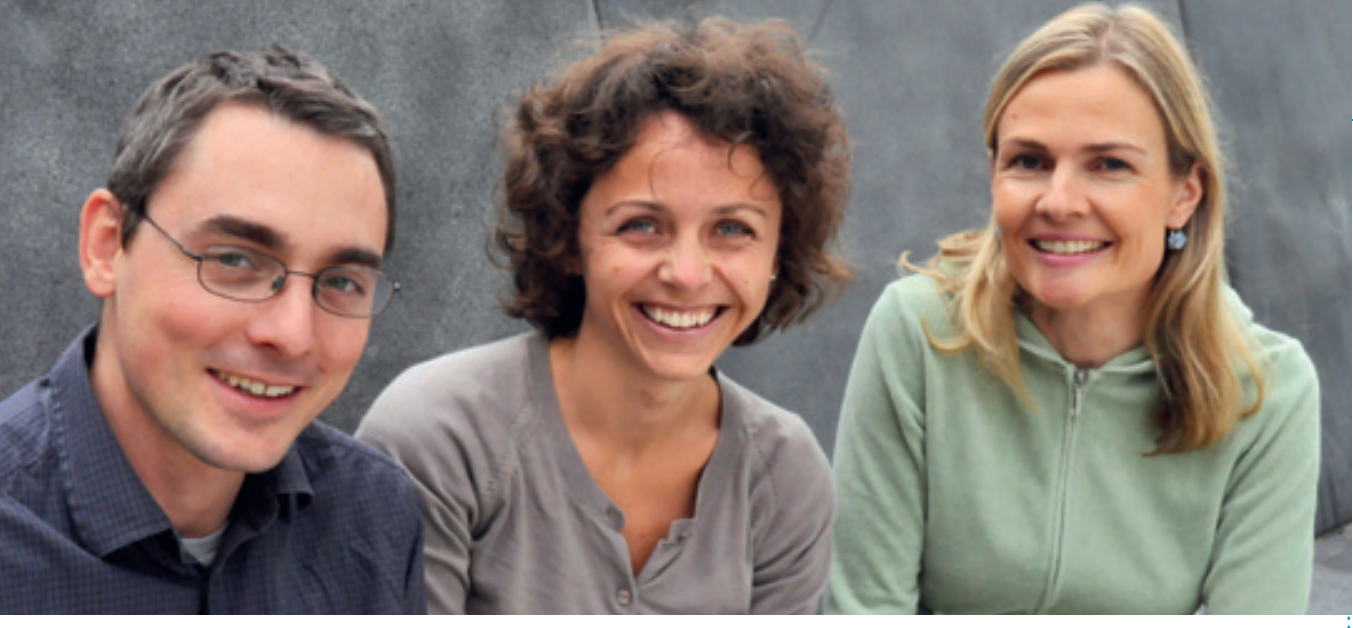

Sébastien Wälchli, Ingerid Weum Abrahamsen og Johanna Olweus, studiens tredje-, første- og sisteforfatter. Foto Lars-Egil Fallang

\title{
T-cellebasert immunterapi ved kreft
}

\author{
Ny norsk studie gir håp om at bruk av målstyrte T-celler kan føre til mer
} effektiv behandling med mindre bivirkninger ved leukemi og lymfekreft.

T-celler helbreder oss for infeksjoner uten bivirkninger fordi de har reseptorer som kan gjenkjenne peptider fra fremmede agens med høy grad av spesifisitet. Hos en pasient med kreft, derimot, angriper immunsystemet oftest ikke kreftcellene, fordi de ikke blir erkjent som fremmede og farlige. T-celler fra en frisk giver kan imidlertid gjenkjenne kreftcellene hos en pasient som fremmede pga. genetiske forskjeller mellom giver og pasient. Dette er bakgrunnen for at stamcelletransplantasjon, der T-celler følger med i transplantatet, kan kurere leukemi og lymfekreft. Dette kalles transplantat-mot-leukemi-effekt. Problemet er at T-cellene ofte gjenkjenner og dreper også normale celler og dermed forårsaker såkalt transplantatmot-vert-sykdom, noe som ofte innebærer alvorlige komplikasjoner og i verste fall $\mathrm{d} ø \mathrm{~d}$.

- Vi har laget en ny metode for å identifisere T-celler som kan gi en målstyrt transplantat-mot-leukemi-effekt, sier Johanna Olweus ved Oslo universitetssykehus, Radiumhospitalet (1). Disse T-cellene kan drepe med høy grad av spesifisitet ved at T-cellene gjenkjenner proteiner som er selektivt uttrykt på bestemte celletyper i blod og beinmarg. Slike T-celler har vi normalt ikke i sirkulasjonen, noe som forhindrer autoimmunitet. Forskerne omgår denne såkalte toleransen ved å introdusere T-cellene for peptider fra normalt uttrykte proteiner i kompleks med et fremmed vevstypemolekyl (HLA).

- Med denne metoden blir det generert T-celler fra friske givere som kan drepe pasientens B-celler spesifikt og effektivt, inkludert kreftceller fra pasienter med kronisk lymfatisk leukemi. T-cellene gjenkjenner peptider fra det B-cellespesifikke proteinet CD20. Spesifisiteten kan forklares ved at en stor andel av T-cellereseptorene fra disse T- cellene har en felles struktur. Slike T-celler, eller deres reseptorer, kan brukes i behandling av pasienter med B-celleleukemi eller lymfekreft.
- Terapeutiske antistoffer er i dag den raskest voksende legemiddelklassen, og har svært lovende resultater, selv om få pasienter er kurert. Antistoffene retter seg mot celletypespesifikke proteiner og ikke kreftspesifikke proteiner, som er vanskelige å identifisere. Vi ønsker å videreføre dette prinsippet til T-cellebasert immunterapi. T-celler dreper ved andre mekanismer enn antistoffer og kjemoterapi. I motsetning til antistoffer kan T-celler også gjenkjenne intracellulære proteiner, noe som dramatisk øker antall terapeutiske mål, siden flertallet av proteiner er intracellulære, sier Olweus. Hun fremhever at familiene til Øyvind André Grøseth og Børge Moen Stjern, som begge døde av leukemi, har vært viktige inspirasjonskilder og har samlet inn forskningsmidler til prosjektet.

\section{Translasjonsforskning ved kreft}

Johanna Olweus er professor og leder forskergruppen ved Seksjon for immunologi, Institutt for kreftforskning, Oslo universitetssykehus, Radiumhospitalet. Gruppen arbeider med å generere nye former for T-cellebasert immunterapi ved kreft. Legene Ingerid W. Abrahamsen og Erlend Strønen har vært viktige for utvikling av den nye metoden, og forsker Sébastien Wälchli har vært sentral for utviklingen av analyser for å identifisere T-cellereseptorsekvensene. Translasjonsforskningen er et samarbeid med Fridtjof Lund-Johansen og klinikere ved Rikshospitalet samt professor Ton Schumacher i Amsterdam, en av verdens ledende tumorimmunologer.

\section{Erlend Hem}

erlend.hem@medisin.uio.no

Tidsskriftet

\section{Litteratur}

. Abrahamsen IW, Stronen E, Wälchli S et al. Targeting B cell leukemia with highly specific allogeneic $T$ cells with a public recognition motif. Leukemia 2010; doi: 10.1038/leu.2010.186.

\section{Ordforklaringer}

T-cellereseptor: En T-celles T-cellereseptor gjenkjenner et bestemt vevstypemolekyl - et HLA-molekyl - som viser frem et peptid (proteinfragment). T-cellene har et stort repertoar av reseptorer som gjenkjenner ulike HLA-peptidkomplekser på overflaten av nesten alle kroppens celler. T-cellene «skanner» kroppens celler for peptider fra fremmede og skadelige agens (f.eks. virus), som har infisert cellene. Når en T-cellereseptor gjenkjenner og binder et slikt HLA-peptidkompleks på en målcelle, kan T-cellen aktiveres til å drepe målcellen.

Toleranse: T-celler som med høy affinitet kan binde peptider fra kroppens egne normalt uttrykte proteiner i kompleks med HLA, fjernes under utviklingen av immunsystemet. Dette resulterer i såkalt sentral toleranse og er viktig for at vi normalt mangler T-celler i sirkulasjonen som kan forårsake autoimmune sykdommer.

\section{Allogen hematopoetisk stamcelletrans-} plantasjon: Transplantasjon av blodstamceller fra en frisk giver (allogen giver) til en pasient. Stamcellene høstes direkte fra beinmarg eller fra blod etter at giveren har fått behandling med en vekstfaktor. Pasient og giver har samsvarende vevstype (HLA-type). T-celler medfølger stamcellene i transplantatet og kan forårsake både transplantat-mot-leukemi-effekt og transplantat-mot-vert-sykdom. Siden man ikke kan forutsi hvilken av effektene som vil dominere, er behandlingen farlig, men den utgjør eneste kurative terapi for en del pasienter med leukemi eller lymfekreft.

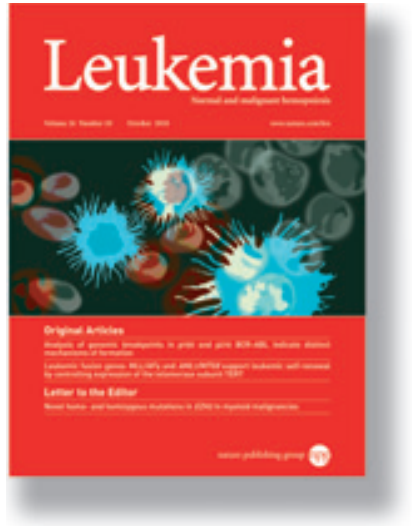

Artikkelen ble e-publisert 16.9. 2010 i det velrenommerte tidsskriftet Leukemia (www.nature.com/leu)

\section{Tips oss}

Er du iferd med å publisere eller har du nylig publisert iet internasjonalt tidsskrift? Send tips til erlend.hem@medisin.uio.no 